\title{
The Effect of Proflavin, Ethidium Bromide and an Elevated Temperature on the Appearance of Nisin-negative Clones in Nisin-producing Strains of Streptococcus lactis
}

\author{
By WITOLD KOZAK, MARIANNA RAJCHERT-TRZPIL AND \\ W七A D YS七AW T. DOBRZAŃSKI \\ Department of Molecular Genetics, Institute of Biostructure, \\ Medical Academy, 02-004 Warsaw, Poland
}

(Received 17 December 1973; revised 21 February 1974)

\section{SUMMARY}

In some nisin-producing strains of Streptococcus lactis, clones which were permanently incapable of producing nisin $\left(\mathrm{Nis}^{-}\right)$appeared spontaneously with a frequency of 0.03 to $0.82 \%$. Treatment with proflavin (Pro), ethidium bromide (EB) or at a temperature of $40^{\circ} \mathrm{C}$ increased the number of such clones. In one strain $78 \%$ of cells became Nis- after treatment with Pro.

Treatment with nitrosoguanidine did not reverse the effect of Pro or EB. There was no evidence that Pro or EB selected spontaneously-occurring Nis- clones.

These observations suggest that the gene(s) responsible for nisin production in some $S$. lactis strains may be located on a plasmid, but further investigation is required to confirm this.

\section{INTRODUCTION}

Nisin is a polypeptide antibiotic produced by some strains of Streptococcus lactis (Mattick \& Hirsch, 1944). Genetic and biochemical information on the synthesis of nisin is lacking (Hurst \& Paterson, I97I). Some strains are known to lose the $\mathrm{Nis}^{+}$character temporarily or permanently for unknown reasons.

The aim of the present work was to check the effect of proflavin, ethidium bromide and an elevated temperature on the appearance in populations of nisin-producing $S$. lactis strains of nisin-negative clones. In one strain the effect of rifamycin was also checked. These substances are used to 'cure' bacteria from plasmids (Courvalin, Carlier \& Chabbert, I972; Novick, 1969; Riva, Fietta, Silvestri \& Romero, 1972).

\section{METHODS}

Bacterial strains. There were I 2 nisin-producing Streptococcus lactis strains and a test strain of Streptococcus cremoris I 5 for nisin detection. The strains were obtained from the Institute of Milk Industry, Warsaw, Poland; the Department of Pure Milk Cultures, Olsztyn, Poland and the Department of Technical Microbiology of the Kódź Institute of Technology, Lódź, Poland. The strains were kept in a Io \% suspension of powdered skim milk in water at $4{ }^{\circ} \mathrm{C}$ and transferred weekly in this medium.

Media. Peptonized milk (Difco) supplemented with Io g glucose/1; pH before autoclaving $7 \cdot 2$; either liquid medium (PM), or medium solidified by the addition of $1 \cdot 5 \%$ agar (PMA) was used.

Chemicals. Ethidium bromide (EB), Boots Pure Drug Co.; proflavin (Pro), Loba Chemie, 
Austria; rifamycin (Rif), Calbiochem; $N$-methyl- $N^{\prime}$-nitro- $N$-nitrosoguanidine (NTG), K \& K Laboratories, USA; streptomycin (Str), Polfa, Poland.

The detection of nisin production. Colonies were replicated to Petri dishes containing PMA which had previously been flooded with an $18 \mathrm{~h}$ culture of the test strain, S. cremoris IP5, diluted $\mathrm{r}: \mathrm{IO}$. After $\mathrm{I} 8 \mathrm{~h}$ of incubation the appearance of inhibition zones round the replicated colonies was recorded.

Apparent $\mathrm{Nis}^{-}$colonies were isolated and grown for $\mathrm{I} 8 \mathrm{~h}$ in PM medium. Total nisin (endo- and exocellular) was assayed by the method of Hurst (1966). As a rule each assay was made twice.

Sensitivity of strains to proflavin, ethidium bromide and rifamycin. This was tested by (i) the serial dilution method in PM medium - after $18 \mathrm{~h}$ incubation the minimal inhibitory concentration (m.i.c.) of these substances was determined; (ii) after $18 \mathrm{~h}$ incubation the growth of strains was compared on PMA medium without any additions with the growth of these strains on PMA with Pro or EB. The growth on PMA medium was scored +++ , on PMA with Pro or EB,+++++ or + .

The treatment of strains with proflavin, ethidium bromide, rifamycin or elevated temperature. (i) Incubation with Pro, EB or Rif (Courvalin et al. 1972): I 8 h cultures of streptococci in PM medium were diluted $\mathrm{I}: 50$ and plated $(0.2 \mathrm{ml} /$ Petri dish) on PMA medium with or without various concentrations of the above-mentioned compounds. After $\mathrm{I} 8 \mathrm{~h}$ incubation, the colonies were washed off with saline $(0.85 \% \mathrm{NaCl})$ and the suspensions appropriately diluted with the same solution and plated on PMA medium to obtain single colonies. (ii) The strain was incubated in PM medium for $18 \mathrm{~h}$ at $40{ }^{\circ} \mathrm{C}$ and subsequently, after appropriate dilution in saline, plated on PMA medium to obtain single colonies. The ability to produce nisin was checked in individual colonies after incubation.

The permanence of the inability to produce nisin in nisin-negative clones. (i) The $\mathrm{Nis}^{-}$clones were passaged ten times and the ability to produce nisin checked after each passage. (ii) The $\mathrm{Nis}^{-}$clones unable to produce nisin after ten passages were treated with NTG (20 or $200 \mu \mathrm{g} /$ $\mathrm{ml}$ ) for $30 \mathrm{~min}$ in PM medium. After removal of the NTG by washing the cells twice, the suspension of bacteria was plated on PMA medium to obtain single colonies and the ability to produce nisin was examined.

With the exception of the cases where it is stated that a temperature of $40^{\circ} \mathrm{C}$ was used, all incubations were at $30^{\circ} \mathrm{C}$.

\section{iR ES ULTS}

Initial observations on the occurrence of nisin-negative clones in S. lactis strains spontaneously and after treatment with proflavin or ethidium bromide

The occurrence of $\mathrm{Nis}^{-}$clones and the influence of Pro and EB on their appearance was checked in 12 nisin-producing strains. The sensitivity of these strains to the two compounds was first determined, so that appropriate doses could be chosen. For the various strains the m.i.c. for proflavin was 4 to $12 \mu \mathrm{g} / \mathrm{ml}$ and for ethidium bromide $0.5-2.5 \mu \mathrm{g} / \mathrm{ml}$. In the experiments Pro was used at $7.5 \mu \mathrm{g} / \mathrm{ml}$ and EB at $2 \cdot 0 \mu \mathrm{g} / \mathrm{ml}$. Since no selection method for the ability to produce nisin is available only a limited number of clones could be examined in the experiments. The results are presented in Table $\mathrm{r}$.

Some 300 to 1450 colonies were examined for each strain. Among colonies from control cultures Nis- clones were isolated from only three strains, one from each. After Pro or EB treatment such clones were isolated from eight strains. In two of these strains $(45,5 \mathrm{I})$ Pro and/or EB treatment possibly increased the frequency of occurrence of $\mathrm{Nis}^{-}$strains; in a third strain (49) this effect was very pronounced. 
Table I. Occurrence of Nis- clones in I 2 nisin-producing strains of $S$. lactis, untreated or treated with Pro or EB

\begin{tabular}{|c|c|c|c|c|c|c|}
\hline \multirow{3}{*}{$\begin{array}{c}\text { S. lactis } \\
\text { strain } \\
\text { no. }\end{array}$} & & & \multicolumn{4}{|c|}{ Treated strains } \\
\hline & \multicolumn{2}{|c|}{ Untreated strains } & \multicolumn{2}{|c|}{ Pro $(7.5 \mu \mathrm{g} / \mathrm{ml})$} & \multicolumn{2}{|c|}{$\mathrm{EB}(2 \cdot 0 \mu \mathrm{g} / \mathrm{ml})$} \\
\hline & $\begin{array}{l}\text { No. colonies } \\
\text { examined }\end{array}$ & $\begin{array}{l}\text { No. Nis } \\
\text { colonies }\end{array}$ & $\begin{array}{l}\text { No. colonies } \\
\text { examined }\end{array}$ & $\begin{array}{l}\text { No. Nis-- } \\
\text { colonies }\end{array}$ & $\begin{array}{l}\text { No. colonies } \\
\text { examined }\end{array}$ & $\begin{array}{l}\text { No. Nis } \\
\text { colonies }\end{array}$ \\
\hline 2 & $144 \mathrm{I}$ & o & 1169 & 0 & $62 \mathrm{I}$ & o \\
\hline 27 & 796 & 0 & I055 & I & 429 & I \\
\hline 28 & 656 & 0 & 1003 & o & 340 & 0 \\
\hline 29 & 516 & 0 & 1032 & 0 & 432 & 0 \\
\hline 38 & 326 & 0 & 523 & I & 479 & 0 \\
\hline 45 & 1448 & I & 527 & 2 & 632 & 2 \\
\hline 49 & 345 & I & $9 \mathrm{I} 4$ & 188 & $32 \mathrm{I}$ & 20 \\
\hline 50 & 914 & 0 & 1323 & 0 & $36 I$ & I \\
\hline $5 \mathrm{I}$ & 623 & 0 & 923 & 3 & 735 & 2 \\
\hline 52 & 298 & I & 814 & 0 & $45 I$ & I \\
\hline 53 & 372 & 0 & 765 & 0 & 388 & 0 \\
\hline 54 & 346 & 0 & $76 I$ & 4 & 607 & 0 \\
\hline
\end{tabular}

Table 2. Occurrence of $\mathrm{Ni}^{-}$clones in S. lactis strain 49/IV, untreated or treated with various concentrations of Pro and EB or a temperature of $40{ }^{\circ} \mathrm{C}$

\begin{tabular}{|c|c|c|c|}
\hline \multirow[b]{2}{*}{ Treatment } & \multicolumn{2}{|c|}{ No. clones examined } & \multirow{2}{*}{$\begin{array}{l}\text { Increase in no. } \\
\mathrm{Nis}^{-} \text {clones* }\end{array}$} \\
\hline & Total & $\mathrm{Nis}^{-}$ & \\
\hline $\begin{array}{l}\text { Untreated } \\
\text { (control) }\end{array}$ & 4248 & $35(0.82 \%)$ & I \\
\hline $\begin{array}{c}\text { Pro }(\mu \mathrm{g} / \mathrm{ml}) \\
5.0 \\
7.5 \\
10.0\end{array}$ & $\begin{array}{l}1660 \\
I 879 \\
2398\end{array}$ & $\begin{array}{r}75(4.40 \%) \\
344(18 \cdot 47 \%) \\
1859(77.52 \%)\end{array}$ & $\begin{array}{r}5 \cdot 37 \times \\
22 \cdot 50 \times \\
94 \cdot 78 \times\end{array}$ \\
\hline $\begin{array}{c}\mathrm{EB}(\mu \mathrm{g} / \mathrm{ml}) \\
0.5 \\
\mathrm{I} \cdot 0 \\
2.5\end{array}$ & $\begin{array}{l}742 \\
385 \\
\text { I } 83\end{array}$ & $\begin{array}{l}38(5.13 \%) \\
38(9.90 \%) \\
16(8.74 \%)\end{array}$ & $\begin{array}{l}6.26 \times \\
12.10 \times \\
10.66 \times\end{array}$ \\
\hline Temperature of $40^{\circ} \mathrm{C}$ & I 248 & $14(\mathrm{I} \cdot 12 \%)$ & $\mathrm{I} \cdot 37 \times$ \\
\hline
\end{tabular}

More detailed observations were made on strains 45, 49 and 5I. In our previous investigations (Kozak, Rajchert-Trzpil, Zajdel \& Dobrzański, 1973) no lysogeny was detected in strains 49 or $5 \mathrm{I}$, while strain 45 was lysogenic.

Before the investigations, the strains were passaged 4 or 5 times, with plating to obtain single colonies. For each subsequent passage a colony producing substantial amounts of nisin was taken. The clones obtained from these passages were designated $45 / \mathrm{v}, 49 / \mathrm{rv}$ and $5 \mathrm{I} / \mathrm{V}$.

The occurrence of nisin-negative clones in S. lactis 45/v, 49/IV and 5I/V spontaneously and after treatment with proflavin, ethidium bromide and at $40{ }^{\circ} \mathrm{C}$

Strains $45 / \mathrm{V}, 49 / \mathrm{rV}$ and $5 \mathrm{I} / \mathrm{V}$ were subjected to various concentrations of Pro and EB and to a temperature of $40{ }^{\circ} \mathrm{C}$. Strain $5 \mathrm{I} / \mathrm{V}$ was also treated with Rif (the m.i.c. for Rif for this strain was $\mathrm{I} 5 \mu \mathrm{g} / \mathrm{ml}$ ). The results are presented in Tables 2, 3 and 4 . 
Table 3. Occurrence of $\mathrm{NiS}^{-}$clones in $\mathrm{S}$. lactis strain $5 \mathrm{I} / \mathrm{v}$, untreated or treated with various concentrations of Pro, EB and Rif or a temperature $40^{\circ} \mathrm{C}$

\begin{tabular}{|c|c|c|c|}
\hline \multirow[b]{2}{*}{ Treatment } & \multicolumn{2}{|c|}{ No. clones examined } & \multirow{2}{*}{$\begin{array}{l}\text { Increase in no. } \\
\text { Nis clones* }\end{array}$} \\
\hline & Total & $\mathrm{Nis}^{-}$ & \\
\hline $\begin{array}{l}\text { Untreated } \\
\text { (control) }\end{array}$ & 6728 & $2(0.03 \%)$ & I \\
\hline $\begin{array}{l}\text { Prot } \\
\qquad(5-10 \mu \mathrm{g} / \mathrm{ml})\end{array}$ & 4639 & $28(0.6 \%)$ & $20 \times$ \\
\hline $\begin{array}{l}\text { EB } \\
\qquad(2 \cdot 5-5 \cdot 0 \mu \mathrm{g} / \mathrm{ml})\end{array}$ & 3785 & $9(0.24 \%)$ & $8 \times$ \\
\hline Temperature of $40^{\circ} \mathrm{C}$ & 1717 & $7(0.41 \%)$ & $13 \cdot 6 \times$ \\
\hline $\begin{array}{l}\text { Rif } \\
\qquad(3.75-\mathrm{I} 5.0 \mu \mathrm{g} / \mathrm{ml})\end{array}$ & 2629 & 0 & 0 \\
\hline
\end{tabular}

$*$ Control $=1$.

$\dot{\dagger}$ No differences in the increase of the number of Nis" clones caused by varying the dose (within the examined range) were observed.

Table 4. Occurrence of $\mathrm{Nis}^{-}$clones in S. lactis strain $45 / \mathrm{v}$, untreated or treated with various concentrations of Pro, EB or a temperature of $40^{\circ} \mathrm{C}$

\begin{tabular}{|c|c|c|c|}
\hline \multirow[b]{2}{*}{ Treatment } & \multicolumn{2}{|c|}{ No. clones examined } & \multirow{2}{*}{$\begin{array}{l}\text { Increase in no } \\
\text { Nis }^{-} \text {clones* }\end{array}$} \\
\hline & Total & $\mathrm{Nis}^{--}$ & \\
\hline $\begin{array}{l}\text { Untreated } \\
\text { (control) }\end{array}$ & 24.48 & $I(0.04 \%)$ & I \\
\hline $\begin{array}{l}\text { Pro }{ }^{\dagger} \\
\qquad(1-5 \mu \mathrm{g} / \mathrm{ml})\end{array}$ & 1055 & $6(0.57 \%)$ & $14 \cdot 2 \times$ \\
\hline $\begin{array}{l}\mathrm{EB} \dagger \\
\qquad(0 \cdot 5-2 \cdot 5 \mu \mathrm{g} / \mathrm{ml})\end{array}$ & I 2.5 & $4(0.33 \%)$ & $8 \cdot 2 \times$ \\
\hline Temperature of $40^{\circ} \mathrm{C}$ & 854 & $7(0.83 \%)$ & $20 \cdot 7 \times$ \\
\hline
\end{tabular}

* Control $=\mathrm{I}$.

$\uparrow$ No differences in the increase of the number of $\mathrm{Nis}^{-}$clones due to varying the dose (within the examined range) were observed.

In strain $49 / \mathrm{IV}$, in untreated populations, $0.82 \%$ of clones were $\mathrm{Nis}^{-}$. In populations previously treated with Pro or EB, depending on the agent and its concentration, 4.0 to $78.0 \%$ of such clones were found. No detinite increase of $\mathrm{Nis}^{-}$clones was observed in populations grown at $40{ }^{\circ} \mathrm{C}$.

In strains $45 / \mathrm{V}$ and $5 \mathrm{I} / \mathrm{V}$ the frequency of occurrence of $\mathrm{Nis}^{-}$clones both in treated and untreated populations was considerable, but distinctly lower than in strain 49/IV.

In these strains 0.03 and $0.04 \%$ of $\mathrm{Nis}^{--}$clones respectively were found in untreated cultures. In strain 5I/V 20-, I4- and 8-fold increases in the frequency of nisin-negative clones were observed as a result of the action of Pro, a temperature of $40^{\circ} \mathrm{C}$ and EB, respectively. After Rif treatment among 2629 colonies, no Nis ${ }^{-}$clone was found. Similar results were obtained for strain $45 / \mathrm{v}$.

In strains $45 / \mathrm{V}$ and $51 / \mathrm{V}$ no dependence (within the examined range) of the number of $\mathrm{Nis}^{-}$clones on the dose of applied factors was observed.

Possible causes of the increase in the frequency of occurrence of Nis clones in strains $49 / \mathrm{IV}, 45 / \mathrm{V}$ and $5 \mathrm{I} / \mathrm{V}$ after treatment with Pro, EB or at a temperature of $40{ }^{\circ} \mathrm{C}$ include non- 
Table 5. Sensitivity to proflavin of S. lactis 49/IV clones previously either treated or untreated with proflavin

\begin{tabular}{|c|c|c|c|c|c|}
\hline \multirow[b]{2}{*}{ Clones } & \multirow{2}{*}{$\begin{array}{l}\text { No. } \\
\text { clones } \\
\text { examined }\end{array}$} & \multicolumn{4}{|c|}{ Growth on PMA medium with Pro concn of $(\mu \mathrm{g} / \mathrm{mll})$ : } \\
\hline & & o & 5 & $7 \cdot 5$ & 10 \\
\hline $\mathrm{Nis}^{-} /$Pro & IO & $++t$ & +++ & $++t$ & ++ \\
\hline $\mathrm{Nis}^{+} /$Pro & Io & +++ & $+t+$ & $+t+$ & ++ \\
\hline $\mathrm{Nis}^{-} / \mathrm{C}$ & 5 & +++ & +++ & +++ & $\begin{array}{c}\text { Some clones }++ \\
\text { some clones }+\end{array}$ \\
\hline $\mathrm{Nis}^{+} / \mathrm{C}$ & 7 & +++ & +++ & $+t+$ & $\begin{array}{c}\text { Some clones }++ \\
\text { some clones }+\end{array}$ \\
\hline
\end{tabular}

$\mathrm{Nis}^{-} /$Pro and $\mathrm{Nis}^{+} /$Pro, clones isolated after incubation of the strain with proflavin. $\mathrm{Nis}-/ \mathrm{C}$ and $\mathrm{Nis}^{+} / \mathrm{C}$, clones isolated from cultures untreated with proflavin.,,++++++ , Range of intensity of growth of strains.

Table 6. Sensitivity to ethidium bromide of S. lactis 49/IV clones previously either treated or untreated with ethidium bromide

\begin{tabular}{|c|c|c|c|c|c|}
\hline \multirow[b]{2}{*}{ Clones } & \multirow{2}{*}{$\begin{array}{c}\text { No. } \\
\text { clones } \\
\text { examined }\end{array}$} & \multicolumn{4}{|c|}{ Growth on PMA medium with EB concn of $(\mu \mathrm{g} / \mathrm{ml})$ : } \\
\hline & & 0 & I & 1.5 & $2 \cdot 5$ \\
\hline $\mathrm{Nis}^{-} / \mathrm{EB}$ & 10 & +++ & +++ & +++ & +++ \\
\hline $\mathrm{Nis}^{+} / \mathrm{EB}$ & 9 & +++ & +++ & +++ & +++ \\
\hline $\mathrm{Nis}^{-} / \mathrm{C}$ & 4 & +++ & +++ & +++ & $\begin{array}{l}\text { ones } t+ \\
\text { lones } t+\end{array}$ \\
\hline $\mathrm{Nis}^{+} / \mathrm{C}$ & 8 & +++ & +++ & +++ & $\begin{array}{l}\text { ones }+ \\
\text { lones }+\end{array}$ \\
\hline
\end{tabular}

$\mathrm{Nis}^{-} / \mathrm{EB}$ and $\mathrm{Nis} / \mathrm{EB}$, clones isolated after incubation of the strain with ethidium bromide. $\mathrm{Nis}^{-} / \mathrm{C}$ and $\mathrm{Nis}^{+} / \mathrm{C}$, clones isolated from cultures untreated with ethidium bromide.,+++++ , Range of intensity of growth of strains.

hereditary modification, selection of $\mathrm{Nis}^{-}$clones as more resistant to these agents or as having a shorter generation time, mutagenic activity of the applied factors, and elimination of a plasmid carrying the determinant(s) for nisin production. Further experiments were undertaken to check these possibilities.

Stability of $\mathrm{Nis}^{-}$clones originating from populations treated with Pro, EB or at $40{ }^{\circ} \mathrm{C}$

The ability to produce nisin was examined during ten passages in $44 \mathrm{Nis}^{-}$clones from strain $5 \mathrm{I} / \mathrm{V}, 17$ clones from strain $45 / \mathrm{V}$ and 100 clones from strain $49 / \mathrm{IV}$. The clones were obtained after Pro, EB or elevated temperature treatment.

In no case was there a reversion to the ability to produce the antibiotic in the examined clones. It thus seems that these clones are not variants with temporarily changed characters.

\section{Sensitivity to Pro and EB of clones from S. lactis strains previously treated with these substances}

To check whether the selection of $\mathrm{Nis}^{-}$clones as more resistant to proflavin and ethidium bromide than $\mathrm{Nis}^{+}$clones occurs, the sensitivity of $\mathrm{Nis}^{+}$and $\mathrm{Nis}^{-}$clones to these substances was compared. These clones originated from populations either untreated or treated with Pro or EB. The experiments were performed as described in Methods. 
In strain 49/IV, $\mathrm{Nis}^{+}$and $\mathrm{Nis}^{-}$clones isolated from populations treated with Pro or EB do not differ in their sensitivity to the concentrations of these compounds used in the experiments; similarly $\mathrm{Nis}^{+}$and Nis- clones isolated from populations not treated with Pro or EB do not differ in their sensitivity to the concentrations of these compounds used in the experiments. When the sensitivity to Pro or $\mathrm{EB}$ of $\mathrm{Nis}^{+}$and $\mathrm{Nis}^{-}$clones from untreated populations was compared with the sensitivity of such clones from treated populations (Tables 5 and 6 ), no difference was observed in their sensitivity towards the lower concentrations of Pro or EB used in these experiments, concentrations which caused an increase in the frequency of occurrence of $\mathrm{Nis}^{-}$clones in the population. Only certain clones, but both $\mathrm{Nis}^{+}$and $\mathrm{Nis}^{-}$ ones, from treated populations were slightly more resistant to the highest of the Pro and EB concentrations used than the $\mathrm{Nis}^{+}$and $\mathrm{Nis}^{-}$clones from untreated populations; this increase in resistance was essentially the same in $\mathrm{Nis}^{+}$and $\mathrm{Nis}^{-}$clones.

Similar investigations were performed on $39 \mathrm{Nis}^{+}$and $\mathrm{Nis}^{-}$clones of strain $5 \mathrm{I} / \mathrm{V}$ and 20 clones of strain $45 / \mathrm{V}$ from untreated and treated populations. No differences in sensitivity to Pro or EB were observed.

\section{Comparison of the growth of $\mathrm{Nis}^{+}$and $\mathrm{Nis}^{-}$clones}

The increased frequency of appearance of $\mathrm{Nis}^{--}$clones after Pro or EB treatment could possibly be due to the greater rate of division of $\mathrm{Nis}^{-}$cells.

The kinetics of growth of populations of two $\mathrm{Nis}^{-}$(obtained after Pro treatment) and two $\mathrm{Nis}^{+}$clones of strain $49 / \mathrm{IV}$ in liquid medium were compared. No differences in the rate of growth were observed.

\section{The growth of Nis' and Nis clones in a mixed culture}

The possibility of the domination of $\mathrm{Nis}^{-}$over $\mathrm{Nis}^{+}$clones in a mixed culture was examined.

Cultures of $\mathrm{Nis}^{+}$and $\mathrm{Nis}^{-}$clones (diluted I : 100) of strains $45 / \mathrm{V}$ and $5 \mathrm{I} / \mathrm{V}$ were used. The Nis - clones came from populations treated with Pro, the $\mathrm{Nis}^{+}$clones from untreated populations. The $\mathrm{Nis}^{-}$and $\mathrm{Nis}^{+}$clones of the same strain were mixed in the proportions $\mathrm{I}$ : IoO and 5:95, respectively. The mixed culture was incubated for $20 \mathrm{~h}$, and samples taken every $4 \mathrm{~h}$ were plated on PMA medium and the ratio of viable $\mathrm{Nis}^{+}$to $\mathrm{Nis}^{-}$cells was determined.

In all samples the proportions of $\mathrm{Nis}^{-}$to $\mathrm{Nis}^{+}$cells were close to the initial ratio. Thus no dominance of $\mathrm{Nis}^{-}$over $\mathrm{Nis}^{+}$clones was shown.

\section{The permanence of inability to produce nisin in $\mathrm{Nis}^{-}$clones mutagenized with $N T G$}

One of the characteristic properties of plasmids is the fact that a cell cured of a plasmid cannot regain the feature determined by the plasmid, by means of mutation. It was therefore checked whether NTG treatment could restore the ability to produce nisin in Nis- clones originating from populations treated with Pro, EB or at $40{ }^{\circ} \mathrm{C}$. These investigations were performed on $\mathrm{Nis}^{-}$clones of strains $5 \mathrm{I} / \mathrm{V}$ and $49 / \mathrm{IV}$ as described in Methods.

We examined 30730 colonies originating from four Nis- NTG-treated clones of strain $5 \mathrm{I} / \mathrm{V}$, and $20 \mathrm{II} 5$ colonies derived from two Nis ${ }^{-}$NTG-treated clones of strain 49/IV. No $\mathrm{Nis}^{+}$colonies were found.

\section{DISCUSSION}

Our results show that in some nisin-producing strains of $S$. lactis, Nis- clones appeared spontaneously with considerable frequency $(0.03$ to $0.82 \%)$. The treatment of $\mathrm{Nis}^{+}$strains in 
appropriate conditions with Pro, EB or elevated temperature $\left(40^{\circ} \mathrm{C}\right)$ increased the frequency of occurrence of $\mathrm{Nis}^{-}$clones in the population. In one of the three strains examined, $78 \%$ of clones became $\mathrm{Nis}^{-}$after treatment with Pro or EB.

Control experiments indicated that the appearance of $\mathrm{Nis}^{-}$clones in populations of the examined strains after treatment with Pro or EB was not due to a temporary modification or to selection of $\mathrm{Nis}^{-}$clones.

In Nis- clones obtained from populations treated with these substances it was not possible to restore the ability to produce nisin by mutagenesis with nitrosoguanidine. The Nis- clones isolated from populations treated with EB or Pro remain highly resistant to nisin (Kozak, Rajchert-Trzpil and Dobrzański, unpublished observations).

It should perhaps also be checked whether Pro and EB are mutagenic in strains $45 \mathrm{v}$ and $5 \mathrm{I} / \mathrm{V}$. We have performed preliminary experiments to examine the influence of these substances on the frequency of occurrence of streptomycin-resistant mutants. No distinct mutagenic effect was observed. However, because of variations in the results of particular experiments we were unable to determine whether mutations are not induced by these substances, or whether either substance causes a slight increase in the frequency of mutations in the examined gene (unpublished data).

The problem of the possible mutagenic activity of these factors in strain 49/1V is of lesser importance. In this strain, as a result of Pro or EB treatment a considerable proportion of cells in the population permanently lost the ability to produce nisin. The participation of mutations in this phenomenon, if it occurs at all, could only be slight.

Ethidium bromide, proflavin and an elevated temperature are well-known factors in the elimination of plasmids from cells (Courvalin et al. 1972; Novick, 1969). Our work thus suggests that the gene(s) responsible for nisin production may be located on plasmids in some $S$. lactis strains.

To support this hypothesis physico-chemical investigations on the presence of nonchromosomal DNA in cells are necessary. We are making such investigations.

Genetic methods are also valuable in demonstrating the presence of plasmids (see Novick, I969). These methods could not hitherto be applied to $S$. lactis. Recently, the possibility of transduction in S. lactis has been reported (McKay, Cords \& Baldwin, 1972), and it will thus perhaps be possible to apply transduction to test for the presence of plasmids in S. lactis.

The demonstration of the plasmid nature of the determinant of nisin production could have valuable implications in the basic and practical investigations on S. lactis, in particular on the choice of strains for industrial nisin production.

The data on the localization of the genes responsible for the production of antibiotics in micro-organisms are so far scant. The plasmid nature of antibiotic determinants has only been shown in the case of some bacteriocins (Novick, I969). They are not, however, classical antibiotics. Moreover, there are some unconfirmed preliminary data on the plasmid character of determinants of two antibiotics produced by Streptomyces kasugaensis (Okanishi, Ohta \& Umezawa, 1970).

We thank Mrs Zofia Chada, Mrs Jolanta Sikorska and Mr S. Sikorski for expert technical assistance. This work was supported by the Polish Academy of Sciences within Project $09 \cdot 3 \cdot 1 \cdot 3 \cdot 4$. 


\section{REFERENCES}

Courvalin, P. M., Carlier, C. \& Chabbert, Y. A. (1972). Plasmid-linked tetracycline and erythromycin resistance in group D Streptococcus. Annales de l'Institut Pasteur 123, 755-759.

Hurst, A. (1966). Biosynthesis of the antibiotic nisin by whole Streptococcus lactis organisms. Journal of General Microbiology 44, 209-220.

Hurst, A. \& PATERSON, G. M. (I97I). Observations on the conversion of an inactive precursor protein to the antibiotic nisin. Canadian Journal of Microbiology $\mathbf{1 7}, 1370-1384$.

Kozak, W., Rajchert-Trzpil, M., Zajdel, J. \& Dobrzański, W. T. (1973). Lysogeny in lactic Streptococci producing and not producing nisin. Applied Microbiology 25, 305-308.

Mattick, A. T. R. \& HiRsCH, A. (1944). A powerful inhibitory substance produced by group $\mathrm{N}$ streptococci. Nature, London 154, 551-552.

McKay, L. L., Cords, B. R. \& Baldwin, K. A (1973). Transduction of lactose metabolism in Streptococcus lactis $\mathrm{C2}$. Journal of Bacteriology $1 \mathbf{1 5}, 8 \mathrm{10}-8 \mathrm{I} 5$.

Novick, R. P. (1969). Extrachromosomal inheritance in bacteria. Bacteriological Reviews 33, 210-263.

Okanishi, M., Ohta, T. \& Umizawa, H. (1970). Possible control of formation of aerial mycelium and antibiotic production in Streptomyces by episomic factors. The Journal of Antibiotics 23, 45-47.

Riva, S., Fietta, A. M., Silvestri, L. G. \& Romero, E. (1972). Effect of rifampicin on expression of some episomal genes in E. coli. Nature New Biology 235, 78-80. 